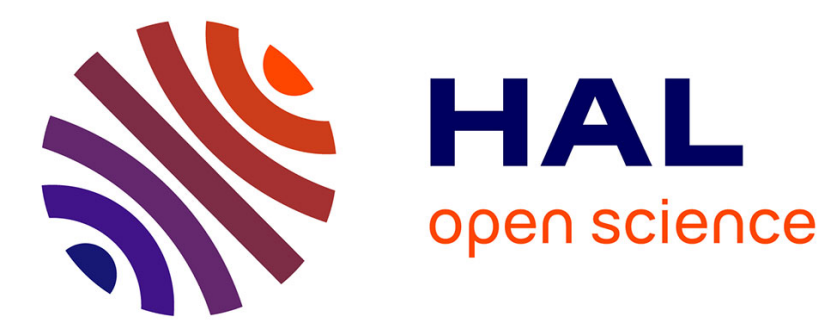

\title{
High temperature furnaces for small and large angle neutron scattering of disordered materials
}

\author{
J. Blétry, P. Tavernière, C. Senillou, P. Desré, M. Maret, P. Chieux
}

\section{To cite this version:}

J. Blétry, P. Tavernière, C. Senillou, P. Desré, M. Maret, et al.. High temperature furnaces for small and large angle neutron scattering of disordered materials. Revue de Physique Appliquée, 1984, 19

(9), pp.725-730. 10.1051/rphysap:01984001909072500 . jpa-00245246

\section{HAL Id: jpa-00245246 \\ https://hal.science/jpa-00245246}

Submitted on 1 Jan 1984

HAL is a multi-disciplinary open access archive for the deposit and dissemination of scientific research documents, whether they are published or not. The documents may come from teaching and research institutions in France or abroad, or from public or private research centers.
L'archive ouverte pluridisciplinaire HAL, est destinée au dépôt et à la diffusion de documents scientifiques de niveau recherche, publiés ou non, émanant des établissements d'enseignement et de recherche français ou étrangers, des laboratoires publics ou privés. 


\title{
High temperature furnaces for small and large angle neutron scattering of disordered materials
}

\author{
J. Blétry $\left({ }^{1}\right)$, P. Tavernière $\left({ }^{2}\right)$, C. Senillou, P. Desré \\ Laboratoire de Thermodynamique et Physico-Chimie Métallurgiques, \\ ENSEEG, Domaine Universitaire, B.P. 75, 38402 Saint Martin d'Hères, France \\ M. Maret and P. Chieux \\ Institut Laue-Langevin, 156X, 38042 Grenoble Cedex, France
}

\begin{abstract}
Résumé. - Deux fours similaires haute température (jusqu’à $2000^{\circ} \mathrm{C}$ ) ont été réalisés respectivement pour des expériences de diffraction neutronique et de diffusion aux petits angles. Ils fonctionnent sous vide et le résistor constitué par une fine feuille de tungstène est alimenté par deux tiges en tantale et écranté par des feuilles en tungstène maintenues dans une boîte de tantale. Dans le faisceau de neutrons, ces fours produisent un très faible bruit de fond (sans pic de Bragg) grâce aux ouvertures réalisées dans le résistor, les écrans et la boîte en tantale pour le libre passage des faisceaux incident, transmis et diffusé aux petits angles. La correction d'absorption de ces fours est ainsi très facile. La température est mesurée par un thermocouple de platine; les hautes températures sont obtenues par visée pyrométrique. Une enceinte à vide a été spécialement dessinée pour le four petits angles avec 2 fenêtres en saphir poli. Ces fours ont été utilisés avec succès pour l'étude des alliages liquides sur les spectromètres D4, D11 et D17 de l'ILL.

Abstract. - Two similar high temperature furnaces (up to $2000^{\circ} \mathrm{C}$ ) have been developed for large angle and small angle neutron scattering (SANS) experiments respectively. They are vacuum furnaces with a thin tungsten foil heating element supplied by two tantalum leads, and shielded by thin tungsten foils maintained in a tantalum box. In a neutron beam, the furnaces produce a very low scattering level (without any Bragg peaks) due to the openings in the heating element, the shields and the tantalum box for the incident, unscattered beam and the scattered beam at low angles. Thus the furnace absorption correction is also much easier. A platinum thermocouple controls temperature, very high temperatures are measured optically. A vacuum chamber has been especially designed for SANS experiments with two windows in polished sapphire. The furnaces have been successfully used for the study of liquid alloys on the D4, D11 and D17 spectrometers at the ILL.
\end{abstract}

For disordered polyatomic systems the determination of partial structure factors and their corresponding partial pair correlation functions is the only unambiguous approach to the microscopic local order. It requires very accurate structure factor determinations since the commonly used isotopic substitution technique produces only minor modifications of the neutron scattering pattern. It also requests measurements at very high $k$ values $\left(k=\frac{4 \pi}{\lambda} \sin \theta, 2 \theta\right.$ being

(1) Present address : St. Gobain Recherche, 39, quai Lefranc, B.P. 135, 93304 Aubervilliers Cedex, France.

$\left({ }^{2}\right)$ Present address : Régie Nationale des Usines Renault, 92109 Boulogne-Billancourt Cedex, France. the scattering angle) for accuracy in the real space representation and at very low $k$ (small angle scattering) for determination of the medium and long range order and verification of the thermodynamic limit. In the case of molten alloys, molten salts, etc... we are of course faced with problems related to high temperature technology. We shall present in this paper two high temperature furnaces ( $T$ up to $2000^{\circ} \mathrm{C}$ ) which have been designed to minimize the background level related to the sample environment on the liquid spectrometer D4 and on the small angle neutron machines D11/D17. As we have said this background must be as small as possible considering the very small signal related to the isotopic substitution, and it must not change with time nor temperature. The basic concepts of these furnaces were initially 
developed for high temperature mass spectrometric measurements [1]. Both furnaces were developed several years ago and were used occasionally since.

\section{Principles.}

1.1 A HIGH TEMPERATURE FURNACE FOR THE HOT SOURCE D4 LIQUID SPECTROMETER. - The structure factors being rather smooth functions of the scattering angle, they do not require a very high instrumental resolution. However, the Bragg peak contamination of the measurements produced by any polycrystalline material disposed along the monochromatic beam path should be avoided for quantitative studies. Due to temperature, corrosion or geometrical modifications of the sample environment, a satisfactory correction of these Bragg peak contaminations is never possible. At relatively low temperatures, $T \lesssim$ $1100{ }^{\circ} \mathrm{C}$, vanadium which is essentially an incoherent scatterer is a commonly used material for containers, heaters and thermal shields. It is not however without defaults since, even on D4 and prohibitively on D17/ D11, its low angle scattering will be affected by aging and corrosion. Moreover, for accurate work, several small Bragg peaks are noticeable and critically depend on the orientation of the material in the beam. At higher temperatures, new incoherent scattering materials are needed, and we must multiply the number of heat shields. «Zero alloys » i.e. alloys with compensating scattering lengths have not been fully investigated yet for this purpose. However, even for pure incoherent scatterers, the problem of multiple screens correction is rather difficult to treat since it implies angular dependent self absorption and shading corrections in and without the presence of the sample. If on the other hand polycrystalline materials are used we may try to reduce the forest of Bragg peaks produced by the multiplicity of screens, with a system of Soller slits disposed between the sample environment and the detector. The D4 instrument being equipped with small linear position sensitive detectors, the only satisfactory solution would be an oscillatory radial Soller slit device. It was not available at the time of the furnace construction. And still now it is not clear that it will be satisfactory for measurements down to $1.3^{\circ}(2 \theta)$, with a hot source beam, and with a statistical accuracy as good as $1 / 1000$. The solution to the problem was therefore found along the standard procedures developed for liquid spectrometers i.e. combination of sample environment geometrical design and choice of appropriate materials. It can be summarized as follows : materials disposed at distances greater than about $25 \mathrm{~cm}$ from the sample are not detected due to an appropriate set of slits in front of the multidetector; at shorter distances, polycrystalline materials should be prohibited along the monochromatic beam path, but are tolerated along the scattered beam if they are distributed continuously over the investigated scatter- ing angles. In practice, a large $(\varnothing 50 \mathrm{~cm})$ vacuum vessel surrounds the sample, it is part of the D4 instrument [6] and is also designed in such a way as to reduce the background at low scattering angles. It is in that vessel that the furnace detailed in the following section, is installed. Of course, there remains the problem of the container. A possible answer, which has been experimented, is a single crystal sapphire container oriented off-scattering [2].

\subsection{A HIGH TEMPERATURE FURNACE FOR D11/D17. -} On the small angle machines, the long wavelengths chosen avoid the problems related to Bragg scattering and in this respect open the choice to a large variety of materials for the sample environment in disordered materials studies. However, most of the materials investigated up to now (single crystals, polycrystalline materials, glasses or amorphous samples) scatter at low angle. Worse, their small angle scattering is extremely sensitive to aging, corrosion, impurity contents, etc... and therefore, indirectly to temperature. Surface smoothness and surface reactivity is also a problem. We are therefore led to solutions as for D4. Materials along the neutron beam should be prohibited, especially in the hot parts. Deposits should be avoided on cold windows. Reactivity and aging of the containers should be tested, a special care being given to compatibility of materials at higher temperatures in vacuum. Of course, depending on the small angle range investigated, different compromises are found (see for example Jal et al. [7], for a workable solution with molten salts, and alkali metals at $T<1200^{\circ} \mathrm{C}$ ). Since the D11/D17 machines do not provide a clean vacuum environment around the sample, a special vessel with appropriate windows has to be constructed.

\section{Description of the furnaces.}

The two furnaces which shall be called LANS (large angle neutron scattering) and SANS (small angle) furnaces are running under vacuum or under reduced inert gas atmosphere between $100^{\circ} \mathrm{C}$ and $2000^{\circ} \mathrm{C}$. Heating is produced by a radiative tungsten resistor. The furnaces hot parts are made out of tantalum, molybdenum, graphite and tungsten which allows them to be used several times. Except for the severe geometrical constraints imposed by the neutron experiment (no material in the monochromatic neutron beam), the furnace design is made to minimize the thermal leaks.

\subsection{THE LANS FURNACE.}

2.1.1 Heating element and shields. - A drawing of the LANS furnace is presented in figure 1. The heating element is a $0.05 \mathrm{~mm}$ thick tungsten foil pinched in the slits cut in two current supplying tantalum leads (of $6 \mathrm{~mm}$ diameter) and in three other tantalum supporting rods (of $3 \mathrm{~mm}$ diameter) all arranged on a 
$100 \mathrm{~mm}$ diameter circle as shown on the top view of figure 1. The incoming neutron beam goes in between the two tantalum leads and comes out, on the other side, through a $18 \mathrm{~mm}$ large by $33 \mathrm{~mm}$ high,

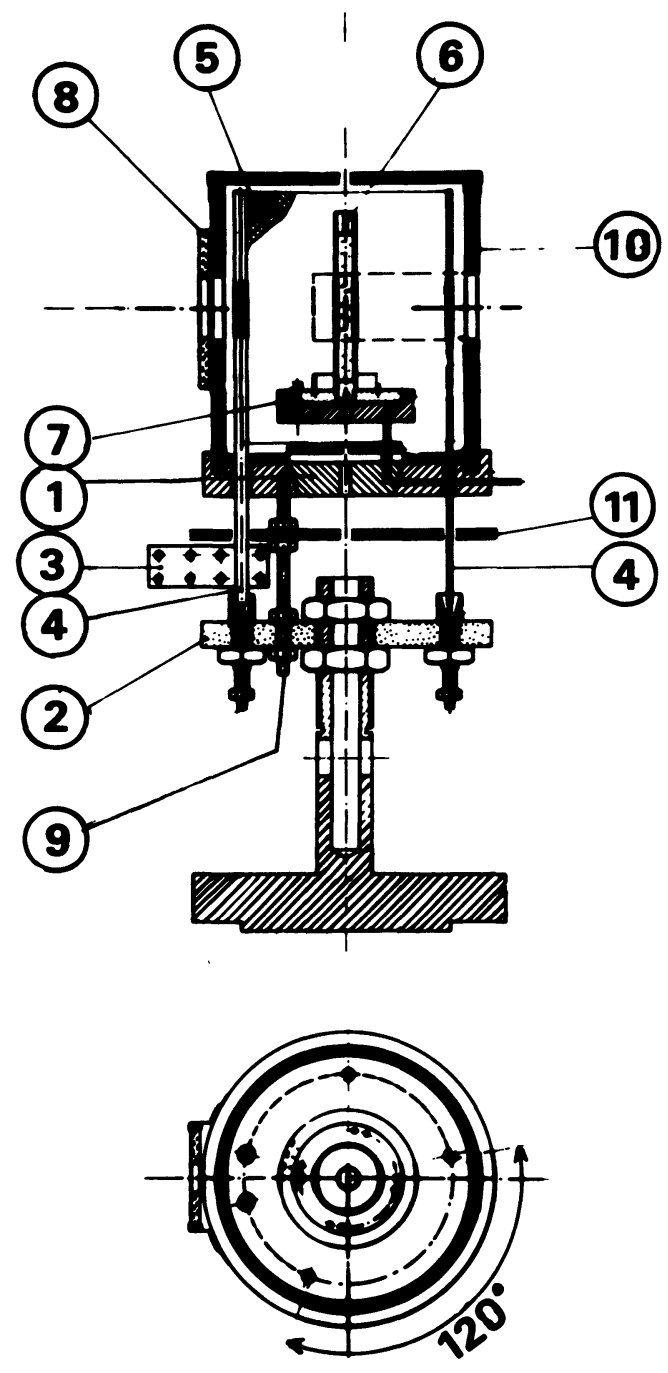

Fig. 1. - The LANS furnace, side drawing and top view. 1 - Graphite sole with a conical insert supporting the cell. 2 - Glass ceramic disk. 3 - Molybdenum current connections. 4 - Tantalum supports and leads for the heating element. 5 - Tungsten heating element. 6 - Sample container. 7 - Molybdenum goniometric table. 8 - Boron nitride window. 9 - Molybdenum rods. $10-$ Tantalum box (124 mm diameter). $11-$ Nickel shields.

window cut in the resistor by photoengraving and electrochemical etching (see Fig. 2). The resistor's design avoids overheating. The tantalum rods are fastened with collet grips on a glass ceramic disk. Thermal shielding is insured by embossed $0.05 \mathrm{~mm}$ thick tungsten foils lined in layers (up to 10) inside a $0.4 \mathrm{~mm}$ thick, $124 \mathrm{~mm}$ diameter tantalum box which confers them a good mechanical strength. A $17 \times$ $32 \mathrm{~mm}$ opening for the incoming beam is cut in the heat shields and in the tantalum box. A boron nitride window fastened to the box limits the beam size (see Fig. 3). An identical opening is cut in the shields for the

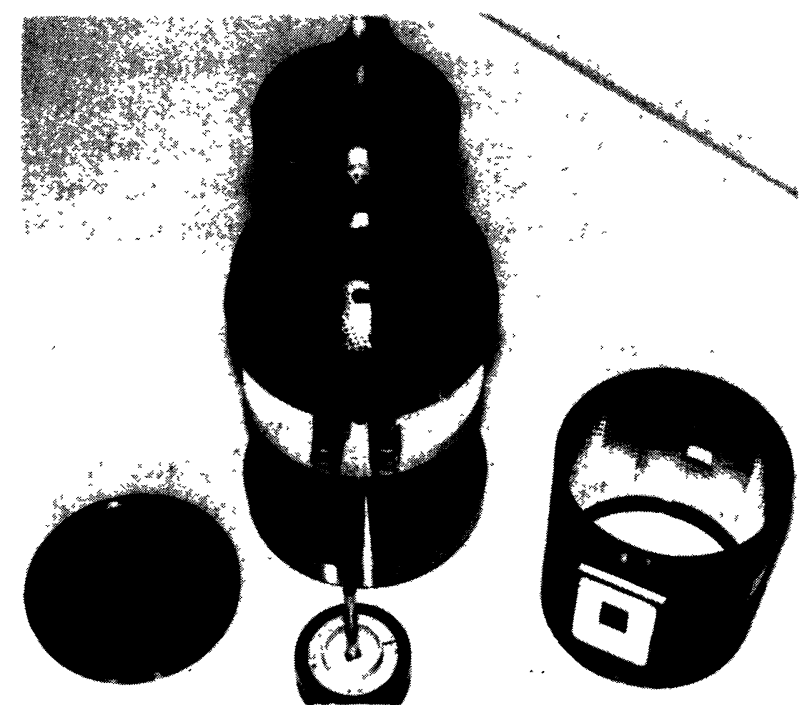

Fig. 2. - Dismounted LANS furnace showing the tungsten foil lined tantalum box with its openings and the attached boron nitride window, the tungsten heating element and the molybdenum goniometric table.

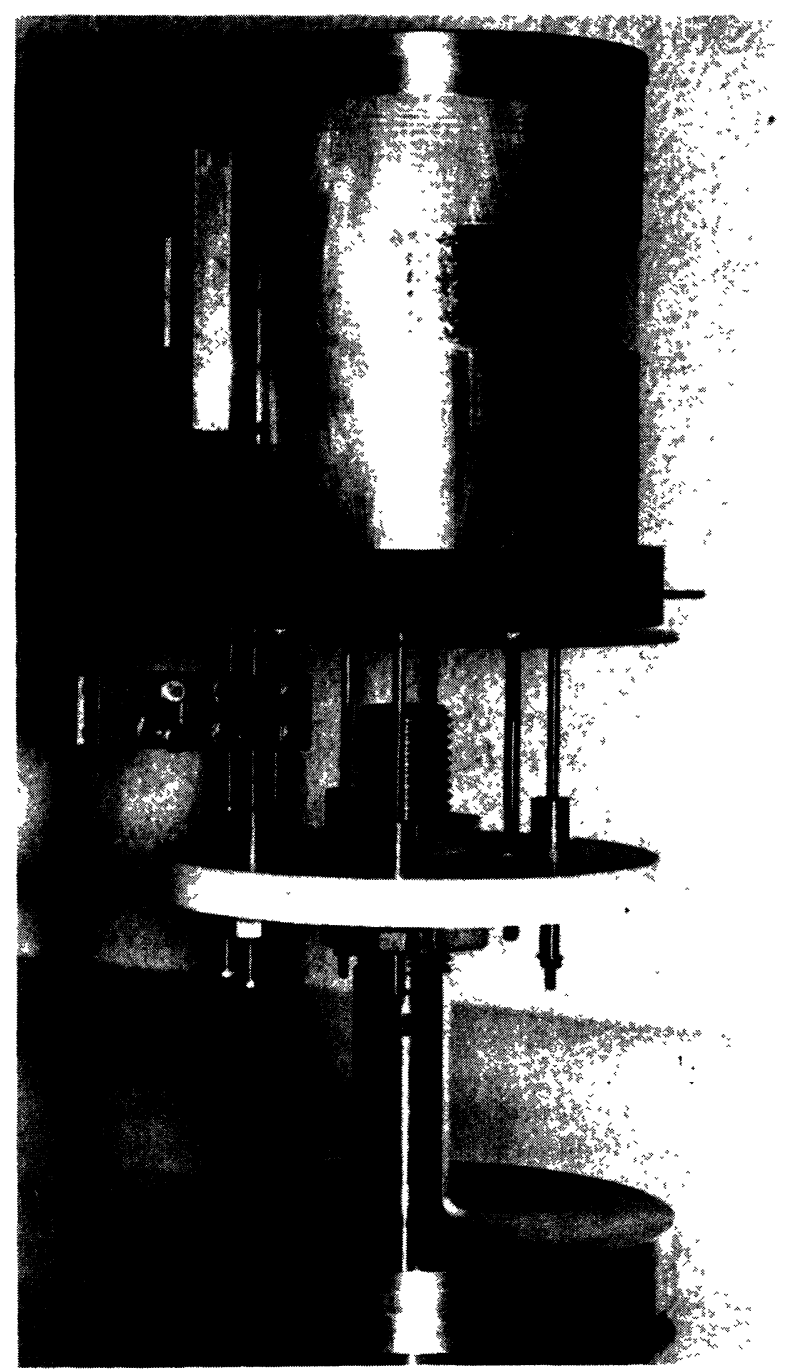

Fig. 3. - Side view of the LANS furnace. See the $120^{\circ}$ opening in the tantalum box. 
transmitted beam and is enlarged to a $120^{\circ}$ opening in the box for the diffracted beam. The tantalum box is placed on a graphite sole, shielded by nickel sheets and fixed to the ceramic plate by three molybdenum rods. A stainless steel base plate supports the whole assembly and insures the furnace centering in the D4 vacuum vessel.

2.1.2 Cell orientation device. - The single crystal sapphire cells which were used for high temperature measurements on liquid alloys [2] were first oriented in the beam and then set slightly off scattering. A graduated molybdenum goniometric table and alumina disk allowed us to rotate the cell in $2.5^{\circ}$ angular steps and then to reproduce its position for the sample measurement (see Fig. 4). Typical cell diameters were about $8 \mathrm{~mm}$, the sample height illuminated by the beam is $33 \mathrm{~mm}$, as defined by the boron nitride window.

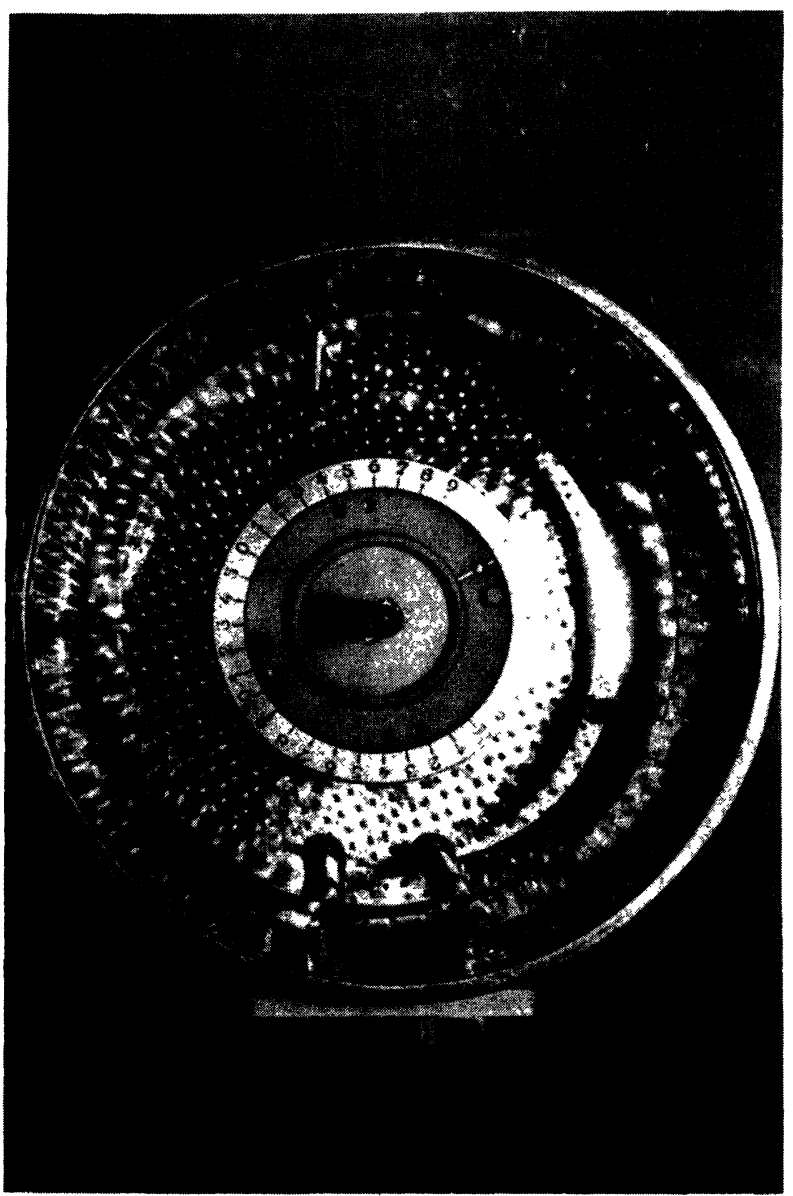

Fig. 4. - Top view of the LANS furnace, with the goniometric table installed.

2.1.3 Power supply and temperature measurement. The LANS furnace is supplied by a $10 \mathrm{kVA}$ (360 A, $30 \mathrm{~V})$ rectifier. We show in figure $5 \mathrm{~A}$, the power versus temperature. For low temperature measurements a thermocouple is introduced through the graphite sole, just below the cell. For high temperatures we use an optical pyrometer, viewing from the center top, through a prism and a silica window directly in the sample cell (small holes are pierced in the center of the tantalum cover, upper shields and cell lid).

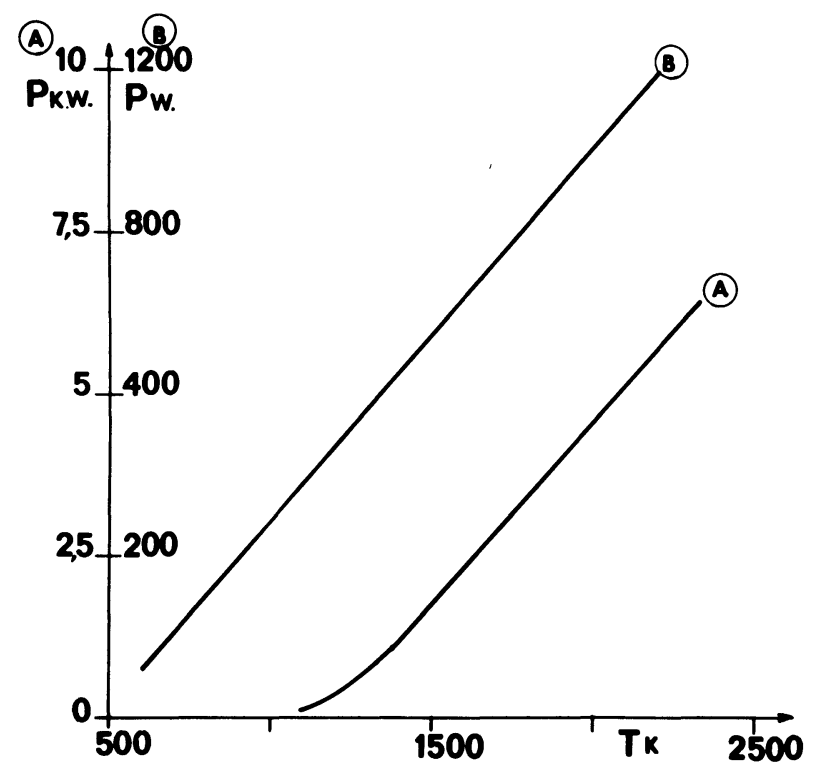

Fig. 5. - Power versus temperature curves, A for the LANS furnace, $B$ for the SANS furnace.

2.1.4 Performances. - For temperatures below $1000^{\circ} \mathrm{C}$, the temperature gradient along the cell is about $10^{\circ} \mathrm{C}$. It decreases at higher temperature. The temperature stability is better than $1^{\circ}$.

The background associated to the furnace scattering is very low (see Fig. 6). The correction for the

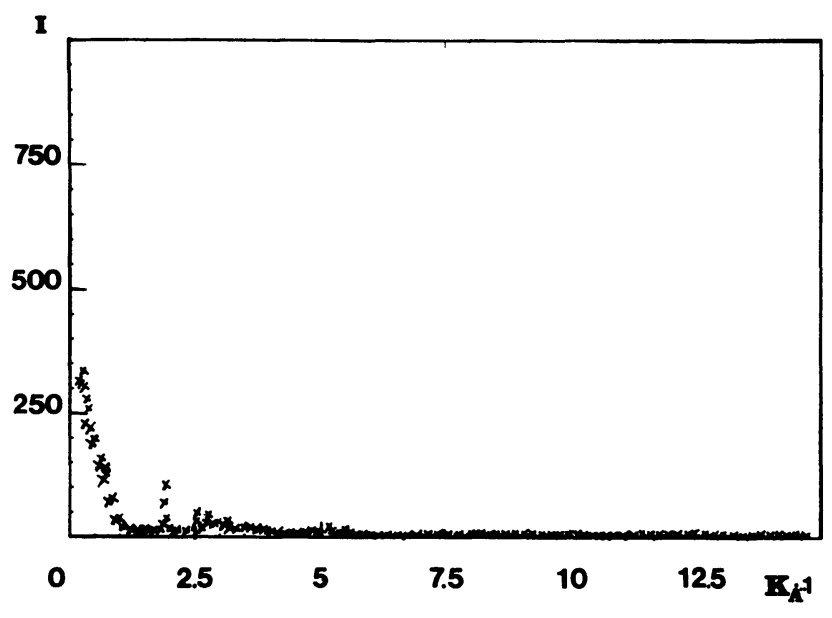

Fig. 6. - Background scattering due to the LANS furnace.

slight attenuation of the scatterer beam by the resistor and heat shields at $2 \theta>2 \theta_{c}$ is easily calibrated with a vanadium standard sample $\left(2 \theta_{c}\right.$ is defined by the angular position of the edge of the transmitted beam window). The scattering due to the sapphire container is equivalent to that of a silica cell and orien- 
tations giving a smaller and flatter signal than that of figure 7a are often found. The furnace was successfully used for the determination of the structure factors of NiV alloys between 1300 and $1600^{\circ} \mathrm{C}$ with sapphire container [2] (see Fig. 7b), and of $\mathrm{CuPb}$ alloys between 950 and $1100^{\circ} \mathrm{C}$ with quartz containers [3].

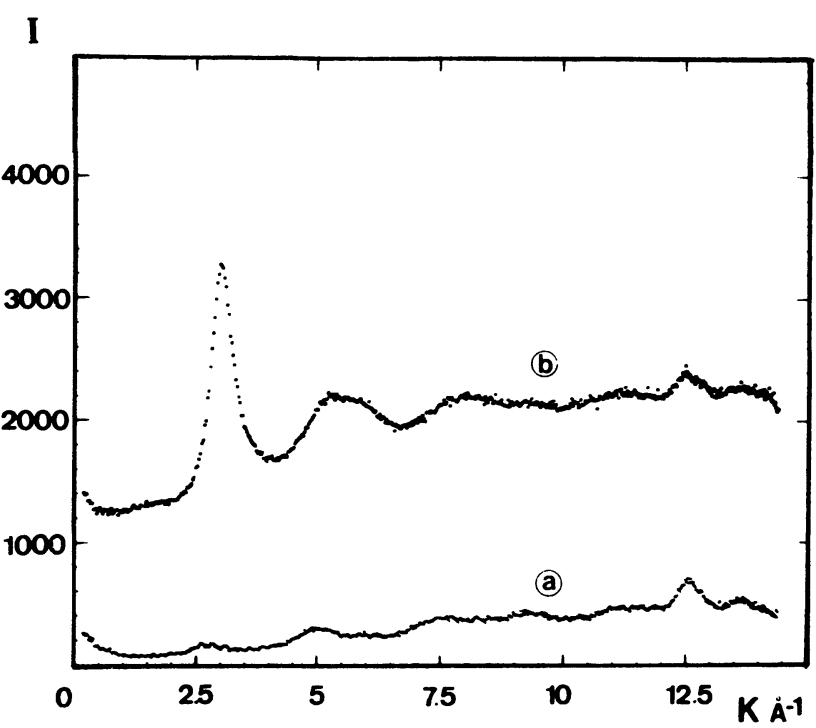

Fig. 7. - a) Background scattering due to the furnace and empty sapphire cell as obtained on the old D4. b) Scattering intensity of a $\mathrm{Ni}_{89} \mathrm{~V}_{11}$ liquid alloy at $1600{ }^{\circ} \mathrm{C}$ in a sapphire cell.

2.2 The SANS Furnace. - Although the construction principles of the two furnaces were identical, the different geometrical constraints led to different designs. In a SANS experiment the detection being insured by a planar detector placed perpendicular to the beam, $25 \mathrm{~mm}$ diameter circular openings were cut in the resistor and the various shields along the beam path. Given the more compact construction of the furnace, these openings were sufficiently large to give way to the scattered beam (the largest scattering angle is about $13^{\circ}$ ) (see Fig. 8). Of course the gain in compacity is also accompanied by a reduction of the power consumption (see Fig. 5, curve B). A boron nitride mask was eventually installed near the sample to define the beam size. A water cooled vessel with polished sapphire windows had to be constructed in order to maintain the furnace in a clean vacuum (or reduced inert gas pressure) (see Fig. 9).

The background scattering due to the furnace is represented on figure 10 . The scattering at $q$ values less than $3 \times 10^{-2} \AA^{-1}$ is essentially due to the sapphire windows. It is independent of temperature. Recent experiments show that other materials could certainly be employed successfully for the cold windows [8].

This furnace was used on D11 and D17 for the study of density and concentration fluctuations in the liquid

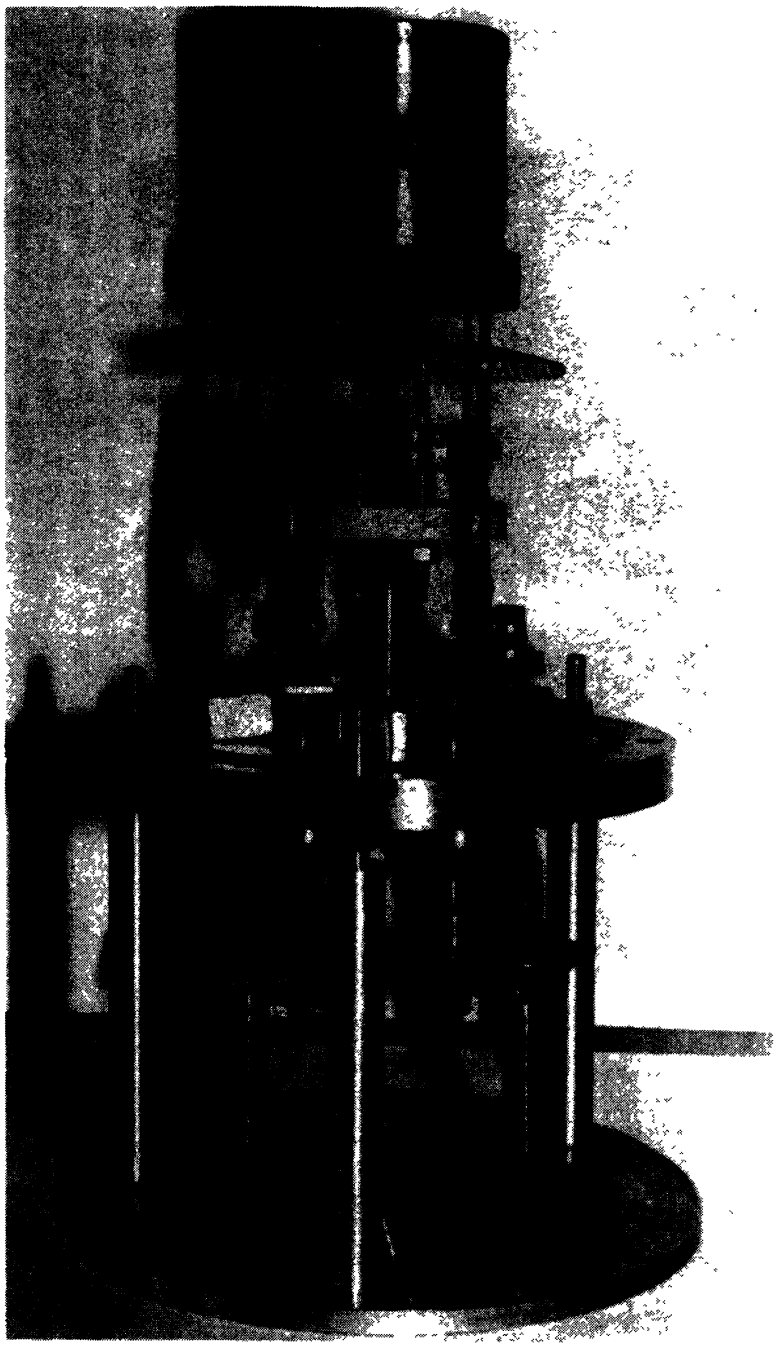

Fig. 8. - The SANS furnace.

alloys $\mathrm{Ag}-\mathrm{Ge}^{4}$ and $\mathrm{Au}-\mathrm{Si}^{5}$, at temperatures up to $1100^{\circ} \mathrm{C}$. When strong signals occur such as in concentration fluctuations measurements, the requirements for very small background are less severe and other designs with thin metallic foils in the beam are workable (see for example Jal et al. [7]).

\section{Conclusion.}

These furnaces which were designed a while ago already should be updated to satisfy the growing needs of high temperature measurements on a large variety of disordered materials. In particular, several points need improvement. The increase in statistical accuracy recently achieved on the D4 machine requests a higher background stability. It implies a very good mechanical stability of the furnace and sample container even at the highest temperatures. A new design of the furnace stand [6], now firmly fixed in a stationary vacuum vessel and the careful avoidance of torsion forces (such as produced by the current leads) should produce satisfactory results. A feedthrough for the encoded rotation of the sample holder on the spectrometer 


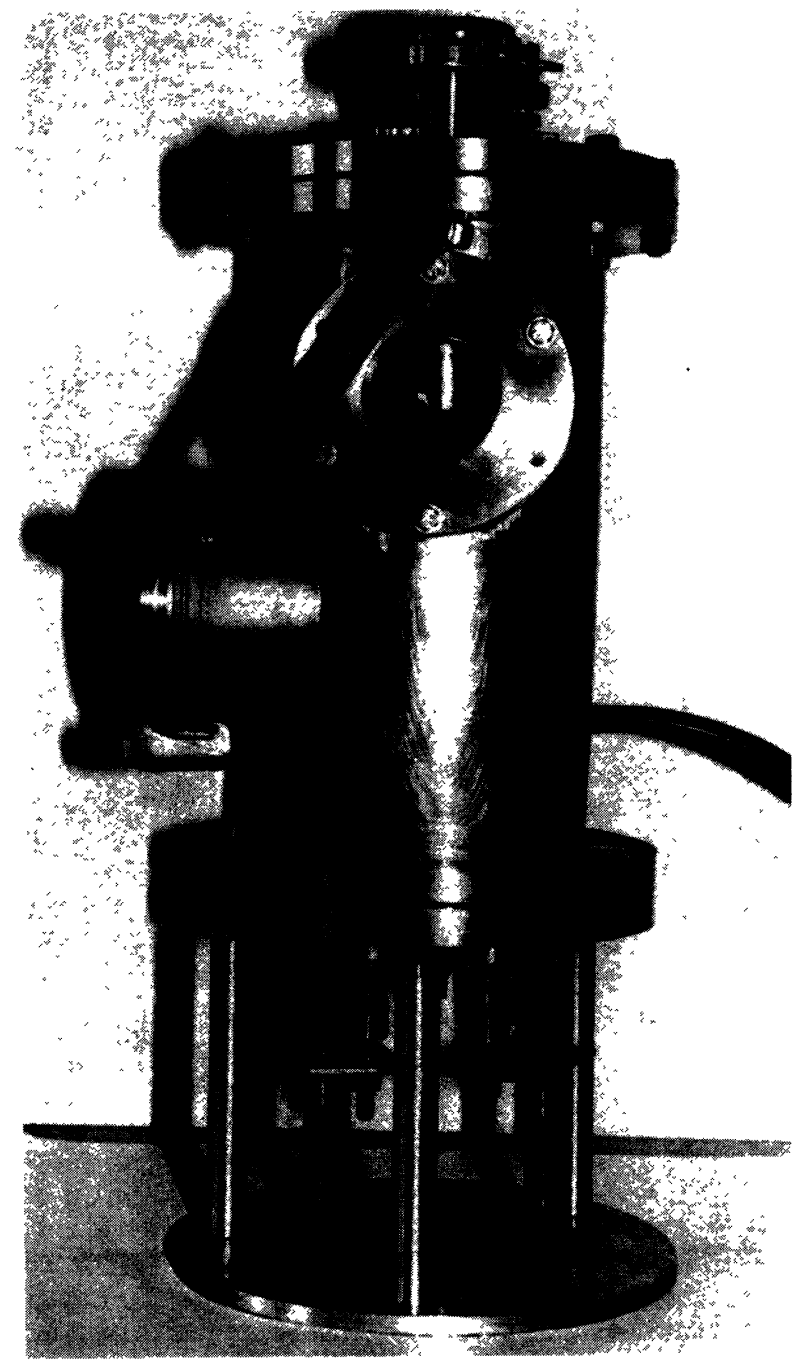

Fig. 9. - Water cooled vacuum vessel for the SANS furnace, with its two polished sapphire windows. axis should permit an accurate alignment of the sapphire cell. And the high divergence of the vertically focused monochromatic beam will require a new set of sintered $\mathrm{B}_{4} \mathrm{C}$ slits. On the small angle machines, as already said, new window materials should be investigated and installed.

Finally, in all cases we should try to significantly shorten the time spent in instalment of furnace, pumping, outgassing and cooling down (problems related to the quality of vacuum or premature opening of the vacuum vessels at the end of tightly scheduled measurements are a major cause of furnace damage).

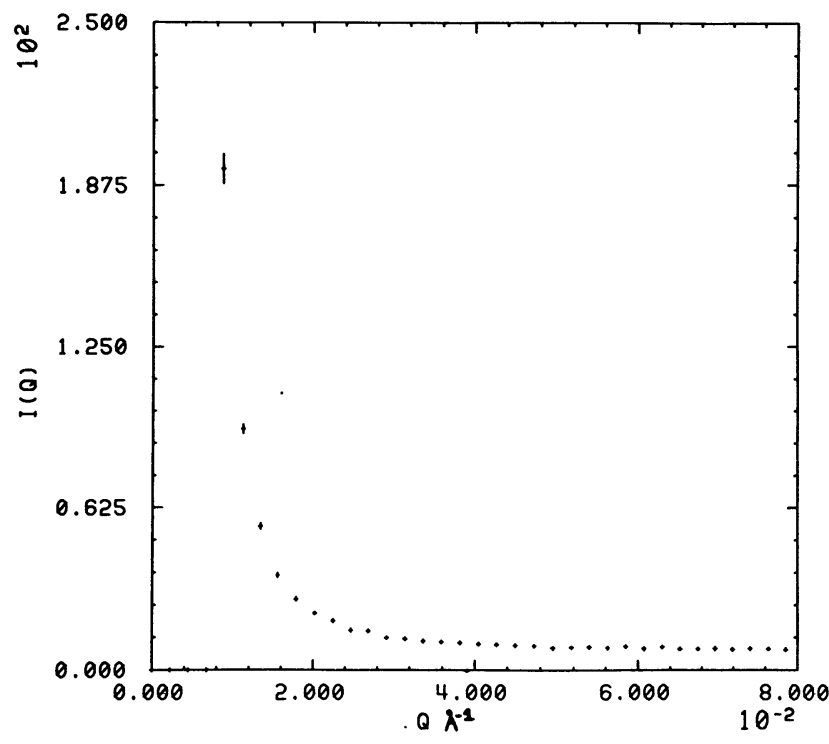

Fig. 10. - The intensity scattered by the SANS furnace mounted on D17 is due to the sapphire windows.

\section{References}

[1] Banon, S., Chatillon, C., Allibert, M., High Temp. Sci. 15 (1982) 105-128.

[2] Lemarchand, J. L., Blétry, J., Desré, P., J. Physique Colloq. 41 (1980) C8-163-166.

[3] Favre-Bonte, M., Blétry, J., Hicter, P., DesRé, P. J., Ja Physique Colloq. 41 (1980) C8-156-159.

[4] Bellissent, $\overline{\bar{M}}$. C., Maret, M., Desré, P., Hicter, P., [8] Chieux, P., Damay, P., LeclercQ, F., to be published. Annual Report ILL (1981) 187.
[5] Tavernière, P., Desré, P., Hicter, P., Senillou, C., Annual Report ILL (1981) 186.

[6] Neutron Research Facilities at the ILL High Flux Reactor, 1st and 2nd Edition (1983).

[7] Jal, J. F., Guiraud, G., Chieux, P., Dupuy, J., J. Phys. E 10 (1977) 977-980. 